\title{
Ecolinguistics in a Multilingual Society: A Case Study of Adekunle Ajasin University, Nigeria
}

\author{
Kehinde Olufemi Ogunyemi \\ Department of Arts Education \\ Adekunle Ajasin University \\ Akungba Akoko, Ondo State, Nigeria \\ E-mail: luckykenny4u@yahoo.com \\ Abiodun Emmanuel Bada \\ Department of Arts Education \\ Adekunle Ajasin University \\ Akungba Akoko, Ondo State, Nigeria \\ E-mail: badaemmy@gmail.com
}

\begin{abstract}
Language, biology, and culture have been intimately related throughout human history. We cannot dispute the fact that we live in an ecolinguistic world, where human beings relate with at least one language. Language has pioneered many interracial relationships and historical milestones. Language is a necessity for basic communication and cultural diversity in human society. In dealing with linguistic aspect of acculturation in a multilingual society, it is pertinent to trace the ecology of language from an individual point of view. This study examined ecolinguistics in a multilingual society using Adekunle Ajasin University as a case study. The research design adopted was descriptive research of survey type. The sample consists of I80 students drawn randomly from the six faculties in the school. Data was collected through a self-constructed questionnaire $(\mathrm{r}=0.79)$ distributed to the students. Data collected was analysed using the descriptive statistics of frequency count and simple percentage for the demographic information of the respondents and analysis of research questions. Findings from the data collected unveil the rate at which Nigeria's native languages are endangered and derogated by foreign languages. Specifically, it was revealed that language is used as the agent of cultural and bio-diversity. Findings of this study also disclosed that English language is predominantly infused into the linguistic culture of the students of Adekunle Ajasin University Akungba-Akoko as it is used as the students' instrument and expression of thoughts. Conclusions are made by looking critically into the making of individuals' bio-cultural diversity. It is then concluded that Nigerian's native languages are considered informal and have a way of limiting ones thought thereby leading to the robustness of foreign language(s) and endangerment of these native languages. This study recommended and advocated for the enrichment and robustness of Nigerian native languages by making sure that our culture is promoted via these native languages.
\end{abstract}

Keywords: Ecolinguistics, Language Endangerment, Bio-Diversity, Cultural Diversity, Multilingual Society,

\section{Background to the Study}

To envisage that language is inexhaustible, linguists across ages have studied it from different perspectives. Sociolinguists see language in relation to the society, thereby relating language with the sociocultural aspect of human being. Psycholinguists study the psychological and neurological factors responsible for language acquisition, comprehension and processing. Haugen (I972) came up with the term Ecolinguistics (ecology of language) to study the interaction of languages and to bridge the dichotomy between the socio and bio-cultural diversity of human being.

Ecolinguistics, in other words ecology of language, is a relatively recent linguistic concept when compared with other classical disciplines and areas of studies in linguistics. In spite of its familiar nature, however, ecolinguistics is not a concept that has a universally acclaimed or accepted definition. It is the study of languages in relation to one another and to various social factors. It has to do with the study of functional interrelationship among languages of the environment. Ecolinguists have an important role to play in eliciting the relationship of individual with the langnuages of the environment.

Language has pioneered many interracial relationships and historical milestones. Language is a necessity for basic communication and cultural diversity in human society. Most human societies happen to be multilingual societies. The question of how to define multilingual society has engaged scholars for quite a long while. Multilingualism is the use of more than one 
language, either by an individual speaker or by a community. The term has not only individual and social, but also an institutional aspect. We talk of "institutional multilingualism" when institution or organizations offer their services with more than one language, as we have it in Adekunle Ajasin University, Akungba-Akoko.

In primordial time, people "ecolinguistically" relate with only one language. God, however, decided to punish them for their presumptuousness in erecting the tower by making them speak different languages (Genesis II:I-II). Thus, multilingualism became an obstacle for further cooperation and thereby led to diversity of culture. People could then only trace their identity not by race nor by religion but by the language do they speak. There, we have the first case of ecolinguistics where necessity was laid upon an individual to relate with the linguistic environment with a given language. So, when two languages meet, then two cultures have met and there is likely to be a lot of changes in that society. The changes will affect the culture and the language of the recipient society or speech community, and the effect will have an impact on the entire recipients' society which in this instance is Nigeria and its citizenry.

We approach the cultural complexities of the human existence by adopting as our object, the even more complex phenomenon of intercultural interaction and linguistic heritage. Our rationale behind adopting intercultural and linguistic heritage as our object in an ecological context is that it requires human beings to interrelate via different cultural and linguistic constraints. With Edgar (1987:28), we can say that the intercultural interaction has its particular dialogic, i.e. it creates a sense of unity, not through merging or assimilation, but through the interplay of complementary, competitive, and antagonistic cultural logics.

Interest in language is a long-standing one, though when it comes to an ecolinguistic one, is a harder question. Linguists tend to view language in terms of forms and their uses in any linguistic world. We cannot dispute the fact we live in an ecolinguistic world where human beings relate with at least one language. An essential theme in our investigation of the linguistic heritage and intercultural interaction above has been the dynamics of identity. The topic of language, discourse and identity has been one of the most widely treated in the newer applied linguistics (Bucholtz and Hall, 2005; De Fina, 2006). The background of this work has taught us that personal identity is not determined by an essential core in the single individual, but rather negotiated in the course of the dialog: identity is an interactional phenomenon, not a discourse-external one. This is also at the core of an ecological understanding of language and identity.

Instead of seeing one's multiple social (language) identities as given by one's position in the social world, an ecological paradigm would see them as many subject positions emerging in the interplay between the social world, biodiversity world, and the discursive situation at hand (Kramsch \& Steffensen, 2008:26).

Language, biology, and culture have been intimately related throughout human history. This relationship is still apparent especially in indigenous, minority, and local societies that maintain close material and spiritual and genetic ties with their society. Traditionally, ecolinguistic knowledge and practices often make indigenous people, minorities, and local communities highly skilled and respectful stewards of language diversity. Local, minority, and indigenous languages are repositories and means of transmission of this knowledge and the related social behaviors, practices, and innovations.

Language is the way children are socialized by adults and the way children learn to guide their inner voice. The central role of language is the way humans communicate with other people and with themselves (Berk \& Winsler, I995; Tabors, I997). This is very crucial because a properly educated person, no matter his field of learning must be able to communicate ideas, principle and information about himself and his environment to the outside world using language. If he has properly grasped the language of instruction, there is no doubting the fact that he will appropriately apply the acquired knowledge as the need arises. There may be problems in making effective use of language in a situation where there is more than one language, a multilingual society.

Multilingualism is a sociolinguistic phenomenon that arises as a result of language contact. It is a situation in which two (i.e. bilingualism, specifically) or more languages operate within the same context. Factors such as political annexation, marital relation, economic transaction, cultural association, educational acquisition and religious affiliation brought about multilingualism. All these factors underpin the socio and bio-cultural landscape of Nigeria today even though the combination of political annexation and economic transaction or exploitation originally brought the people referred to as Nigerians today in contact with the English people.

Through overt and covert means such as trade and commerce, educational policies and ordinances, missionary activities, schools, literature, constitutions, job opportunities and political might, English was successfully entrenched in Nigerians' ecolinguistic world. With the amalgamation of the northern and southern protectorates in I9I4 came the need, in a more crucial dimension, for national life, including nationalist activities, arose the competition of about 450 Nigerian languages, 
the major ones of which include Hausa, Yoruba, Fulani, Kanuri, Ibiobio, Tiv, Ijo, Edo, Urhobo, Nupe, Idoma, just to mention a few.

In Nigeria, like many other African nations, multilingualism is a rule, rather than an exemption. Among the competing languages that scramble for national recognition or official status, whether indigenous or foreign, one must emerge as the official language (the language of administration and education at some levels), language of relevance, from the competitors for the purpose of uniting the nation. Fortunately or unfortunately, English has emerged as that privileged language without which the unity of Nigeria as a nation is mostly improbable, if not outrightly impossible.

This work pictures Adekunle Ajasin University, Akungba-Akoko, Ondo State as a multilingual society where we have hundreds of linguistic representatives. Language is seen as a living entity which has the ability to develop and robust overtime with the help of its users.

This paper explores the value of identity through interaction and discourse. This work regards discursive value of identity as part of ecolinguistics, that is, measures that influence language use. In ecolinguistics, language and identity are often regarded as intrinsically linked (Coupland \& Jaworski 2009).

\section{Statement of the Problem}

In general, there is a big problem since the university (especially Adekunle Ajasin University) departments specialize separately in ecology, linguistics, sociology, psychology or biology, while the issues we face today have intertwined biological, social, linguistic and ecological dimension. Ecolinguistics needs to study different areas of life and use its multidisciplinary perspective to introduce more integrative ways of analyzing the world.

In dealing with linguistic aspect of acculturation in a multilingual society, it is pertinent to trace the ecology of language from an individual point of view. Few speech communities are wholly linguistically homogenous. In other words most societies of the world today are multilingual.

Homo sapiens (human being) are thoroughly cultured species. From birth, even from conception, culture constrains and conditions our human forms of life. As culture shapes our bodies and our relationship, it immerses us and our generation into specific linguistic habit of being in "languaging" with one and another. Language is a product of linguistic habit conditioned by social-cultural and ideological world or environment. From an ecolinguistic point of view, therefore, it becomes an urgent research question to ask how culture and language condition our ecologoical existence: what does linguistic culture do to us, to our relationships, and to the world that we inhabit? What happens to us, as we are unconsciously thrown into this 'tower of babel' where language simultaneously connects with our biological being? How best have we been able to relate with our indigenous language? What is our relationship with foreign languages (especially English)?

\section{Research Questions}

Upon understanding the thrust of Ecolinguistics and multilingualism, the following questions are asked to pilot this study:

- What is English linguistic culture vis-a-vis Nigerian linguistic habit in Adekunle Ajasin University, Akungba-Akoko?

- What is the attitude of Adekunle Ajasin University students' towards native languages?

- Has language been able to function as the agent of cultural and bio-diversity?

- Does the ecology of languages present in Adekunle Ajasin University, Akungba-Akoko have any effect in the endangerment of our native languages?

- What is the state of language robustness in the linguistic situation of Adekunle Ajasin University, Akungba-Akoko?

- What situational factors influence language decision in Adekunle Ajasin University, Akungba-Akoko?

- How in turn has the decisions influenced English Language robustness?

- The above questions place the study at the intersection of the ecolinguistic and sociolinguistic situation of Adekunle Ajasin University, Akungba-Akoko. This intersection is the area of interest for this study.

\section{Significance of the Study}

Recently there has been a great interest in the study of ecolinguistic issues in the world, and scholars have approached the field from different perspectives; including the ecology of language, ecology analysis of discourse, and eco-translation studies.

The contribution of this study will be of interest to sociolinguistic in discourse analyst. "Ecolinguistically", the work will try to keep a balance so that it could be engaging for both language ecologist and linguist without either group feeling patronized. 
This work will examine relationships not only among groups of human but also between humans and the more-than-human world i.e. linguistic world. It is not a mere recapitulation to assert that bio and cultural diversity are distinct features of a multilingual society. It will then be pertinent to trace our relationships with languages in our ecological environment as this work will change our "perspectives" towards our native or natural languages.

\section{Methodology}

The research design used for the collecting and gathering data for this research was descriptive research of survey type. The sample consists of 180 students drawn randomly from the six faculties in Adekunle Ajasin University, Akungba-Akoko, Ondo State, Nigeria. Data was collected through a self-constructed questionnaire $(r=0.79)$ distributed to the students. Data collected was analyzed using the descriptive statistics of frequency count and simple percentage for the demographic information of the respondents and analysis of research questions.

\section{Results}

Upon adopting the above methodology, below are the results of the research presented by answering the stated research questions.

Research question I: What is English linguistic culture Vis-a-viz Nigerian linguistic habit in Adekunle Ajasin University Akungba Akoko?

Data presented on table I would enable answering of this question.

Table I: Responses on English linguistic culture in relation to Nigerian linguistic habit

\begin{tabular}{|c|c|c|c|c|c|c|c|c|}
\hline \multirow[t]{2}{*}{ Items } & \multicolumn{2}{|l|}{ SA } & \multicolumn{2}{|l|}{$\bar{A}$} & \multicolumn{2}{|l|}{$\mathrm{D}$} & \multicolumn{2}{|l|}{$\mathrm{SD}$} \\
\hline & $\mathrm{F}$ & $\%$ & $\mathrm{~F}$ & $\%$ & $\mathrm{~F}$ & $\%$ & $\mathrm{~F}$ & $\%$ \\
\hline English is used as my instrument of thought & 67 & $37.2 \%$ & 90 & $50 \%$ & 16 & $8.9 \%$ & 7 & $3.9 \%$ \\
\hline $\begin{array}{l}\text { There is less stress in expressing thoughts with English } \\
\text { language }\end{array}$ & 46 & $25.6 \%$ & 92 & $51.1 \%$ & 34 & $18.9 \%$ & 9 & $5 \%$ \\
\hline English is the language of the contemporary world & 72 & $40 \%$ & 85 & $47.2 \%$ & 23 & $12.8 \%$ & - & - \\
\hline I acquire English from my indigenous society & 39 & $21.7 \%$ & 58 & $32.2 \%$ & 57 & $31.7 \%$ & 26 & $14.4 \%$ \\
\hline English is my first and only language & I3 & $7.2 \%$ & 34 & $18.9 \%$ & 72 & $40 \%$ & 61 & $33.9 \%$ \\
\hline Average Total & 47 & 26.3 & 72 & 39.9 & 40 & 22.5 & 21 & II.4 \\
\hline
\end{tabular}

Sources: Field work, 2017

Research question 2: What is the attitude of Adekunle Ajasin University students' towards native languages?

Data presented on table 2 would enable answering of this question

Table 2: Responses on Attitude of users towards native language

\begin{tabular}{|c|c|c|c|c|c|c|c|c|}
\hline \multirow[t]{2}{*}{ Items } & \multicolumn{2}{|l|}{ SA } & \multicolumn{2}{|l|}{ A } & \multicolumn{2}{|l|}{$\mathrm{D}$} & \multicolumn{2}{|c|}{ SD } \\
\hline & $\bar{F}$ & $\%$ & $\bar{F}$ & $\%$ & $\bar{F}$ & $\%$ & $\bar{F}$ & $\%$ \\
\hline Native languages limits the expression of ones thought & 27 & $15 \%$ & 56 & $31.1 \%$ & 50 & $27.8 \%$ & 47 & $26.1 \%$ \\
\hline $\begin{array}{l}\text { There is a sense of barbarism in the use of pure native } \\
\text { language }\end{array}$ & 20 & II.I\% & 73 & $40.6 \%$ & 50 & $27.8 \%$ & 37 & $20.6 \%$ \\
\hline Speakers of English are considered to more civilized & 63 & $35 \%$ & 78 & $43.3 \%$ & 27 & $\mathrm{I} 5 \%$ & 12 & $6.7 \%$ \\
\hline Native languages are informal & 37 & $20.6 \%$ & 85 & $47.2 \%$ & $4 \mathrm{I}$ & $22.8 \%$ & 17 & $9.4 \%$ \\
\hline Education should be more of my indigenous language & 39 & $21.7 \%$ & $7 \mathrm{I}$ & $39.4 \%$ & 59 & $32.8 \%$ & II & $6.1 \%$ \\
\hline Average Total & 37 & 20.7 & 73 & 40.3 & 45 & 25.2 & 25 & 13.8 \\
\hline
\end{tabular}

Research question 3: Has language been able to function as the agent of cultural and bio-diversity?

Data presented on table 3 would enable answering of this question 
Table 3: Responses on Language as the agent of cultural and bio-diversity

\begin{tabular}{|c|c|c|c|c|c|c|c|c|}
\hline \multirow[t]{2}{*}{ ITEMS } & \multicolumn{2}{|l|}{ SA } & \multicolumn{2}{|l|}{ A } & \multicolumn{2}{|l|}{$\mathrm{D}$} & \multicolumn{2}{|c|}{ SD } \\
\hline & $\mathrm{F}$ & $\%$ & $\mathrm{~F}$ & $\%$ & $\mathrm{~F}$ & $\%$ & $\mathrm{~F}$ & $\%$ \\
\hline Language is a form of social and biological identity & 92 & $51.1 \%$ & 72 & $40 \%$ & 12 & $6.7 \%$ & 4 & $2.2 \%$ \\
\hline Our culture is reflected most in our native language & $9 \mathrm{I}$ & $50.6 \%$ & 70 & $38.9 \%$ & 16 & $8.9 \%$ & 3 & $1.7 \%$ \\
\hline I have a unique way of using language(s) & $4 \mathrm{I}$ & $22.8 \%$ & IOI & $56.1 \%$ & $3 I$ & $17.2 \%$ & 7 & $3.9 \%$ \\
\hline My language preference enriches our native languages & 56 & $31.1 \%$ & 86 & $47.8 \%$ & 34 & $18.9 \%$ & 4 & $2.2 \%$ \\
\hline $\begin{array}{l}\text { I know at least a friend who is uniquely known for his/her } \\
\text { pure native language usage }\end{array}$ & 73 & $40.6 \%$ & 74 & $4 \mathrm{I} . \mathrm{I} \%$ & 29 & $16.1 \%$ & 4 & $2.2 \%$ \\
\hline Total Average & $7 \mathrm{I}$ & 39.2 & 81 & 44.8 & 24 & 13.6 & 4 & 2.4 \\
\hline
\end{tabular}

Research question 4: Does the ecology of languages present in Adekunle Ajasin University Akungba Akoko have any effect in the endangerment of our native languages?

Data presented on table 4 would enable answering of this question

Table 3: Responses on Ecology of language in Adekunle Ajasin University Akungba Akoko and the endangerment of native languages

\begin{tabular}{|c|c|c|c|c|c|c|c|c|c|}
\hline \multirow[t]{2}{*}{ Items } & \multicolumn{2}{|l|}{ SA } & \multicolumn{2}{|l|}{$\mathrm{A}$} & \multicolumn{2}{|l|}{$\mathrm{D}$} & \multicolumn{2}{|l|}{$\mathrm{SD}$} & \\
\hline & $\bar{F}$ & $\%$ & $\bar{F}$ & $\%$ & $\mathrm{~F}$ & $\%$ & $\mathrm{~F}$ & $\%$ & \\
\hline $\begin{array}{l}\text { I am conscious of the decrease in number of speakers of } \\
\text { my native language }\end{array}$ & 56 & $31.1 \%$ & 92 & $51.1 \%$ & 28 & $15.6 \%$ & 4 & $2.2 \%$ & \\
\hline $\begin{array}{l}\text { Our kinsmen or relatives, anywhere, communicate with } \\
\text { English language }\end{array}$ & I7 & $9.4 \%$ & 73 & $40.6 \%$ & 62 & $34.4 \%$ & 28 & $15.6 \%$ & \\
\hline I perform my daily activities with English language & 47 & $26.1 \%$ & 69 & $38.3 \%$ & 40 & $22.2 \%$ & 24 & $13.3 \%$ & \\
\hline I perform my activities with more than one language & $6 \mathrm{I}$ & $33.9 \%$ & IOI & $56.1 \%$ & I4 & $7.8 \%$ & 4 & $2.2 \%$ & \\
\hline I hailed from a multilingual society & 50 & $27.8 \%$ & 89 & $49.4 \%$ & 33 & $18.3 \%$ & 8 & $4.4 \%$ & \\
\hline Language gains proficiency as its users increases & 75 & $4 \mathrm{I} . \mathrm{I} \%$ & 80 & $44.4 \%$ & 20 & II.I\% & 5 & $2.8 \%$ & \\
\hline $\begin{array}{l}\text { It's unnecessary to speak my native language since my } \\
\text { relatives understand English language }\end{array}$ & 39 & $21.7 \%$ & 29 & I6.I\% & 57 & $31.7 \%$ & 45 & $25 \%$ & \\
\hline $\begin{array}{l}\text { I recognize at least a lecturer in my faculty who code mix } \\
\text { while lecturing }\end{array}$ & 60 & $33.3 \%$ & 94 & $52.2 \%$ & 18 & $10 \%$ & 8 & $4.4 \%$ & \\
\hline I hardly read and write my native language & 45 & $25 \%$ & 68 & 37.8 & 33 & 18.3 & 34 & 18.9 & \\
\hline Total Average & & 50 & 27.7 & 77 & 42.9 & 34 & 18.8 & 17.8 & 9.9 \\
\hline
\end{tabular}

Research question 5: What is the state of language robustness in the linguistic situation of Adekunle Ajasin University Akungba

Akoko?

Data presented on table 5 would enable answering of this question

Table 5: Responses on Situational factors influencing language decision

\begin{tabular}{|c|c|c|c|c|c|c|c|c|}
\hline \multirow[t]{2}{*}{ Items } & \multicolumn{2}{|l|}{ SA } & \multicolumn{2}{|l|}{ A } & \multicolumn{2}{|l|}{$\mathrm{D}$} & \multicolumn{2}{|c|}{$\mathrm{SD}$} \\
\hline & $\mathrm{F}$ & $\%$ & $\mathrm{~F}$ & $\%$ & $\mathrm{~F}$ & $\%$ & $\mathrm{~F}$ & $\%$ \\
\hline English language is used in our religious settings & $8 \mathrm{I}$ & $45 \%$ & 77 & $42.8 \%$ & 16 & $8.9 \%$ & 6 & $3.5 \%$ \\
\hline we use only English language for official purposes & 63 & $35 \%$ & 79 & $43.9 \%$ & 32 & $17.8 \%$ & 6 & $3.3 \%$ \\
\hline English language enriches our knowledge in education & 77 & $39.4 \%$ & 79 & $43.9 \%$ & 19 & $10.6 \%$ & 5 & $2.8 \%$ \\
\hline English is the language of administration & $7 \mathrm{I}$ & $39.4 \%$ & 92 & $51.1 \%$ & I4 & $7.8 \%$ & 3 & $1.7 \%$ \\
\hline $\begin{array}{l}\text { I speak my native language regardless of the situation at } \\
\text { hand }\end{array}$ & 35 & $19.4 \%$ & 75 & $41.7 \%$ & 46 & $25.6 \%$ & 24 & $13.3 \%$ \\
\hline Total Average & 65 & 35.6 & 80 & 44.7 & 25 & I4.I & 9 & 4.9 \\
\hline
\end{tabular}


Research question 6: What situational factors influence language decision in Adekunle Ajasin Akungba Akoko? How in turn the decisions influence English Language robustness?

Data presented on table 6 would enable answering of this question

Table 10: Responses on how the situational factors influence language

\begin{tabular}{|c|c|c|c|c|c|c|c|c|}
\hline \multirow[t]{2}{*}{ Items } & \multicolumn{2}{|l|}{ SA } & \multicolumn{2}{|l|}{ A } & \multicolumn{2}{|l|}{$\mathrm{D}$} & \multicolumn{2}{|l|}{$\mathrm{SD}$} \\
\hline & $\mathrm{F}$ & $\%$ & F & $\%$ & $\mathrm{~F}$ & $\%$ & $\mathrm{~F}$ & $\%$ \\
\hline $\begin{array}{l}\text { Without English language there won't be uniformity of } \\
\text { idea(s) in our native society }\end{array}$ & 59 & $32.8 \%$ & 57 & $31.7 \%$ & $4 \mathrm{I}$ & $22.8 \%$ & 23 & $12.8 \%$ \\
\hline $\begin{array}{l}\text { I have been to places where people do not understand my } \\
\text { native language }\end{array}$ & 67 & $37.2 \%$ & 74 & $4 \mathrm{I.I} \%$ & 23 & $\mathrm{I} 2.8 \%$ & 16 & $8.9 \%$ \\
\hline $\begin{array}{l}\text { I belong to an organization where my native language is not } \\
\text { needed }\end{array}$ & 45 & $25 \%$ & 61 & $33.9 \%$ & 50 & $27.8 \%$ & 24 & $13.3 \%$ \\
\hline $\begin{array}{l}\text { There is a sense of inferiority in speaking my native } \\
\text { language where my friends are communicating with English } \\
\text { language }\end{array}$ & 39 & $21.7 \%$ & 62 & $34.4 \%$ & 53 & $29.4 \%$ & 26 & $14.4 \%$ \\
\hline Total Average & 53 & 29.2 & 64 & 35 & 42 & 23.2 & 22 & I2.4 \\
\hline
\end{tabular}

\section{Discussion of Findings}

The study was carried out on Ecolinguistics in a Multilingual Society in Adekunle Ajasin University Akungba Akoko Ondo State. Findings from research question one has revealed the English linguistic culture Vis-a-vis Nigerian linguistic habit in Adekunle Ajasin University Akungba Akoko; table I shows the English culture in relation to Nigerian linguistic habit in the university. With the number of respondents that agreed, it was revealed that English is used as students' instrument of thought, there is less stress in expressing thoughts with English language and English is the language of the contemporary world. The result from the findings also indicated that students' acquire English from their indigenous society. This means that the students have been able to relate with their environment through language. It is then cleared that western linguistic culture has a great influence on the linguistic habit of Adekunle Ajasin University students.

Findings from research question two revealed the attitude of users towards native language. As shown in table 2, it was indicated that Native languages limits the expression of ones thought, there is a sense of barbarism in the use of pure native language and speakers of English are considered to be more civilized. Also, the result shows that native languages are informal. This means that the use native language in their environment has a way of derogating their personality.

Findings from research question three revealed Language as the agent of cultural and bio-diversity. As shown in table 3 it was indicated that Language is a form of social and biological identity, culture is reflected most in native language and students have a unique way of using language(s). Also the result shows that Students' language preference enriches their native languages and they know at least a friend who is uniquely known for his/her pure native language usage.

Findings from research question four revealed the Ecology of language in Adekunle Ajasin University Akungba Akoko and the endangerment of native languages. As shown in table 4 it was revealed that Students are conscious of the decrease in number of speakers of their native language. Kinsmen or relatives, anywhere, communicate with English language. Students carry out their daily activities with more than one language and they hailed from a multilingual society. The findings also shows that Language gains proficiency as its users increases, many students opine that It is unnecessary to speak native language since their relatives understand English language and students recognize at least a lecturer in their faculty who code mix while lecturing and they hardly read and write their native language.

Findings from research question five revealed the situational factors influencing language decision. As shown in table 5, it was revealed that English language is used in religious settings; students use only English language for official purposes and English language enriches students' knowledge in education. The findings also show that English is the language of administration and students speak native language regardless of the situation at hand.

Finally, findings from research question six as indicated in table 6 revealed the situational factors influencing language. With the number of respondents that agreed with these items it was revealed that Without English language there will not be uniformity of idea(s) in native society. Students have been to places where people do not understand their native language and they belong to an organization where their native language is not needed. It was also indicated that there is a sense of inferiority 
in speaking native language where friends are communicating with English language.

\section{Conclusion}

Masking differences, advocating leveling (striking a balance in the use of LI and L2), defending monolingualism, and stigmatizing the scourge of multilingualism on the one hand, but also speaking in praise of difference and celebrating diversity on the other are all approaches that have been employed ever since people in society have attempted to solve the problems raised by the ambient situation with regard to Ecolinguistics. Some scholars, just like this researcher, even go back to the story of the Tower of Babel where, according to the Bible, men experienced "confusion of language' for the first time for having wanted to raise them to heaven. This work has pictured Adekunle Ajasin University as reflection of tower of babel where necessity is laid upon each and every individual to "ecolinguistically" relate with the environment using one or more language(s).

Based on the findings of this study, it is concluded that the Linguistic culture of English is reflected in the linguistic habit of students of Adekunle Ajasin University thereby leading to the robustness of English language. It is also concluded that the ecology of language present in Adekunle Ajasin University has a way of endangering the native languages.

\section{Recommendation}

Based on the findings of this research, and considering the "ecolinguistic" situations of this part of the world, the following recommendations are made as a panacea to unsatisfactory situation of multilingualism;

- The management of this school should be seen and heard to be more committed in the implementation of a more vibrant and articulate language policy which is expected to usher the school into the twenty-first century sociosensibilities. In tune with Ajulo (1990:18), a usual practice of multilingual countries, whose areas of specialization should cover political, scientific, cultural, literature, technical, literary and philosophical fields is necessarily saddled with the responsibility of creating schools of regional or national interpretation of linguistic codes. In reference to the above assertion, there is need for creation of a language faculty where there would be national and some important regional language departments.

- Government should work on standardization of Nigerian regional or national language such that the need to develop a positive attitude would increase and thereby masking the differences between foreign and native languages. The standardization process in tandem with status planning, actually transforms a minority language into different kind of its users, reconfigures relations of dependence and independence.

- The school management should make provision for promotion of Nigerian cultures by engaging not only the students but members of staff in events and duties that would be culture oriented. Culture, should not only be seen by the school management as only a societal entity but as also, a biological phenomenon that is hereditary.

- Another panacea for national ecolinguistic problem and the associated problem of multilingualism lies in the introduction a bilingual education in foreign languages (especially English) and in a peculiar indigenous language to run, if not throughout the Nigerian educational system, at least to the first year in tertiary institutions. The bilingual education proposed by this study has a great advantage of bolstering the attitudes of all Nigerians to achieve results in their linguistic endeavors and a way of removing the yolk of inferiority complex which is the bane of our society.

- The school management should work with the Government for provision of competent native language lecturers, to bring about reawakening of Nigerian cultural values so that our students can grow up feeling proud of their native languages and culture. The teaching of Nigerian native language must not be restricted to the three Nigerian major languages. Government should train professionals to learn and teach other Nigerian minority languages effectively so as to ensure the robustness of our native languages.

\section{References}

Ajulo, S. (1990) Reflections on Sections $5 I$ and 91 of the 1979 Constitution of the Federal Republic of Nigeria. African Affaits

Berk A. \& Winsler, (1995). Scaffolding children's learning: Vygotsky and early childhood education

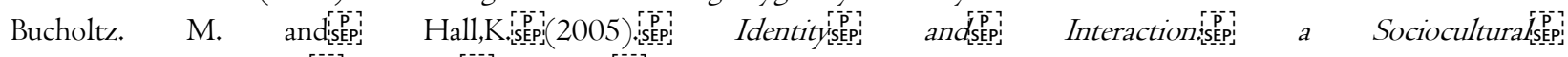

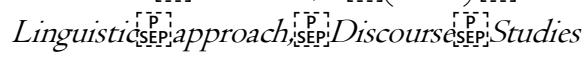


Coupland \& Jaworski (2009). The New Sociolinguistics Reader (2nd Edition).retrieved from https://www.macmillanihe.com/page/detail/the-new-sociolinguistics-reader-nikolas coupland/?sfI =barcode\&st I=978I403944I46. 20/II /20I7

De Fina, A. (2006). Review of 'The Language of Belonging', by U. H. Meinhof \& D. Galasinski. Basinstock: Palgrave. Journal of Sociolinguistics,

Edgar, D. (1987) Focus on Adults: Towards a Productive learning culture (the edgar report). Ministry of education, Victoria Haugen, E. (1972) The Ecology of Language. London: Stanford University Press.

Kramsch, C \& Steffensen.V. (2008). Ecological perspectives on second language acquisition and language socialization. In Patricia Duff \& Nancy Hornberger (eds.), Encyclopedia of Language and Education 8, I7-28. Dordrecht: Springer Verlag.

Tabors, P. (1997) One Child, Two Languages: a guide for Preschool Educators of Children Learning English as a Second Language. Baltimore: Paul Brookes Publishing

\section{Copyrights}

Copyright for this article is retained by the author(s), with first publication rights granted to the journal. This is an open-access article distributed under the terms and conditions of the Creative Commons Attribution license (http://creativecommons.org/licenses/by/4.0/). 